\title{
Child health in complex emergencies
}

William J Moss, a, c Meenakshi Ramakrishnan, ${ }^{b}$ Dory Storms, ${ }^{c}$ Anne Henderson Siegle, ${ }^{c}$ William M Weiss, ${ }^{c}$ Ivan Lejnev, ${ }^{d}$ \& Lulu Muhe ${ }^{d}$

\begin{abstract}
Coordinated and effective interventions are critical for relief efforts to be successful in addressing the health needs of children in situations of armed conflict, population displacement, and/or food insecurity. We reviewed published literature and surveyed international relief organizations engaged in child health activities in complex emergencies. Our aim was to identify research needs and improve guidelines for the care of children. Much of the literature details the burden of disease and the causes of morbidity and mortality; few interventional studies have been published. Surveys of international relief organizations showed that most use World Health Organization (WHO), United Nations Children's Fund (UNICEF), and ministry of health guidelines designed for use in stable situations. Organizations were least likely to have formal guidelines on the management of asphyxia, prematurity, and infection in neonates; diagnosis and management of children with human immunodeficiency virus (HIV) infection; active case-finding and treatment of tuberculosis; paediatric trauma; and the diagnosis and management of mental-health problems in children. Guidelines often are not adapted to the different types of health-care workers who provide care in complex emergencies. Evidence-based, locally adapted guidelines for the care of children in complex emergencies should be adopted by ministries of health, supported by WHO and UNICEF, and disseminated to international relief organizations to ensure appropriate, effective, and uniform care.
\end{abstract}

Keywords Child welfare; Child health services; Emergencies; Disasters; Diarrhea/therapy; Measles/epidemiology; HIV infections/ diagnosis/therapy; Malaria/prevention and control; Nutrition disorders/therapy; Infant mortality; Child mortality; Refugees; Infant, Newborn; Child; Practice guidelines; Review literature (source: MeSH, NLM).

Mots clés Protection enfance; Service santé infantile; Urgences; Catastrophe; Diarrhée/thérapeutique; Rougeole/épidémiologie Infection à VIH/diagnostic/thérapeutique; Paludisme/prévention et contrôle; Troubles nutrition/thérapeutique; Mortalité nourrisson; Mortalité de l'enfant; Réfugié; Nouveau-né; Enfant; Guides de bonne pratique; Revue de la littérature (source: MeSH, INSERM).

Palabras clave Bienestar del niño; Servicios de salud infantil; Urgencias médicas; Desastres; Diarrea/terapia; Sarampión/epidemiología; Infecciones por VIH/diagnóstico/terpia; Paludismo/prevención y control; Trastornos nutricionales/terapia; Mortalidad en la niñez; Mortalidad infantil; Refugiados; Recién nacidos; Niño; Pautas prácticas; Literatura de revisión (fuente: DeCS, BIREME).

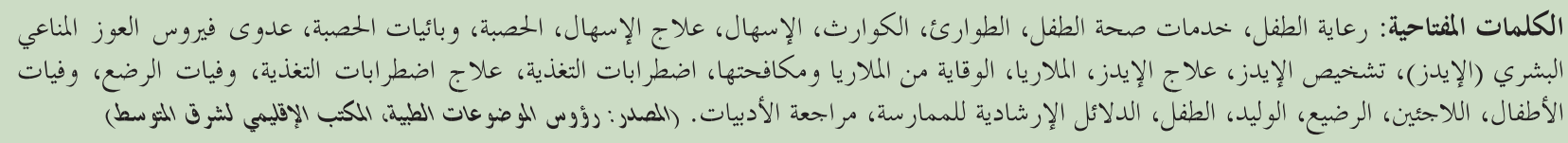

Bulletin of the World Health Organization 2006;84:58-64.

Voir page 62 le résumé en français. En la página 62 figura un resumen en español.

\section{Introduction}

Coordinated and effective interventions are critical for relief efforts to be successful in addressing the health needs of children in complex emergencies. ${ }^{1,2}$ Conflict or disaster often exacerbates the severity and magnitude of childhood diseases, necessitating rapid assessment and treatment of large numbers of severely ill children. Hence, health-care provision in such settings differs from that in stable situations. If the health-care system is not functioning there will be no referral services or supply delivery systems. Health care is often delivered by multiple organizations, with health workers with different levels of qualifications and experience, using diverse guidelines and training materials. Ensuring comprehensive, coordinated, and appropriate care is difficult in such situations.

Guidelines are necessary but not sufficient to ensure optimal care. They define the standard and scope of care, often guide training efforts, and are
يككن الاطلاوع على الملخص بالعر بية في صفحة 63.

important for preparedness planning. However, their effectiveness depends on many conditions: properly trained and supervised health-care workers, adequate and appropriate drug supplies, knowledge of local epidemiology, appropriate health-seeking behaviour, accessible health-care facilities, functioning referral systems, and sufficient funding.

Several factors confound efforts to develop standards and guidelines for the care of children in complex emergencies.

\footnotetext{
a Department of Epidemiology, Bloomberg School of Public Health, Johns Hopkins University, 615 North Wolfe Street, Baltimore, MD 21205, USA. Correspondence should be sent to this author (email: wmoss@jhsph.edu).

b General Preventive Medicine Program, Bloomberg School of Public Health, Johns Hopkins University, Baltimore, MD, USA.

Department of International Health, Bloomberg School of Public Health, Johns Hopkins University, Baltimore, MD, USA.

${ }^{d}$ Department of Child and Adolescent Health and Development, World Health Organization, Geneva, Switzerland.

Ref. No. 04-019570
}

(Submitted: 16 November 2004 - Final revised version received: 7 March 2005 - Accepted: 2 May 2005) 
- The type of emergency - whether an armed conflict, famine, or natural disaster — determines specific health risks and demands responses sufficiently flexible to adapt to these risks.

- At the onset of an emergency, children differ in their baseline health and nutritional status and risk of exposure to communicable diseases. These regional differences persist into the post-emergency phase.

- The health needs of refugee children are not the same as those of internally displaced and internally stranded children, and can differ between acute, chronic, and post-emergency settings.

We have reviewed current child-health guidelines and practices in light of what is known about child morbidity and mortality in complex emergencies. Our aim was to derive recommendations to improve the care of children in complex emergencies and to identify research needs.

\section{Methods}

We reviewed the literature on the causes of morbidity and mortality in children in complex emergencies. We defined complex emergency broadly to refer to a situation of armed conflict, population displacement, and/or food insecurity with associated increases in mortality and malnutrition. We searched English-language articles in the PubMed database using search terms related to child health and complex emergencies, including "complex emergency, "disaster", "refugee", and "war" with "child health" in combination with terms for specific diseases (e.g. "measles", "malaria”, "micronutrient"). Our summary is not intended to be an exhaustive review of this large body of literature. Furthermore, only a small proportion of the collective experience in caring for children in complex emergencies is formally published - most exists as "grey literature" (e.g. institutional scientific and technical reports, conference papers, and theses). Many childhood diseases, such as pneumonia, have not been explicitly studied in complex emergencies; thus health workers in emergencies have extrapolated their etiology, diagnosis, treatment, and prevention from stable situations.
We surveyed international relief organizations providing child care in acute and post-emergency situations. The surveys, conducted by telephone or email using a standard survey instrument, included questions about the qualifications and experience of health-care workers providing care to children within their organization, what guidelines they used, and the limitations of existing guidelines. Surveys were usually conducted with one person at the organization's central office. This approach provided an overview of activities but was sometimes limited by lack of detailed knowledge. Some organizations distributed the questionnaire to individuals with specific expertise. The results are limited by the fact that many organizations function differently in different settings, and the broad results gleaned from the surveys do not capture these differences.

\section{Child morbidity and mortality in complex emergencies Overview}

The highest mortality rates in refugee populations are in children younger than 5 years. ${ }^{3-5}$ Although mortality rates are highest in infants less than 1 year old, the relative increase in mortality is probably greater in older children. 3, 6 One frequently cited example is that of the Kurdish refugees at the Turkey-Iraq border during 1991: 63\% of all deaths were of children younger than 5 years although this group comprised only $18 \%$ of the population. ${ }^{3,4}$ Over several months of the 1992 famine in Somalia, $74 \%$ of children younger than 5 years in displaced persons camps were estimated to have died. ${ }^{7}$ Among Rwandan and Burundian refugees in the Democratic Republic of the Congo in 1996, 54\% of all deaths were among children under 5 years. ${ }^{8}$ In some settings, mortality rates of older children and adults are comparable to or exceed those of young children; this is more probable after outbreaks of cholera or dysentery, or when armed conflict results in many civilian casualties. ${ }^{9,} 10$

During complex emergencies, the most common reported causes of death are the same as the major causes of death in countries with the highest child mortality rates: diarrhoeal diseases, acute respiratory infections, measles, malaria, and severe malnutrition., ${ }^{41}$ The major causes of childhood morbidity and mortality in complex emergencies have not changed significantly in the past decade.
Child health in complex emergencies

For example, in $1999,80 \%$ of deaths in Congolese children younger than 5 years in Lugufu camp in the United Republic of Tanzania were due to malaria, diarrhoea, and pneumonia. ${ }^{12}$

\section{Diarrhoeal disease}

Diarrhoeal disease is a common cause of child morbidity and mortality, and in some settings results in extremely high mortality rates. Outbreaks of cholera have been reported frequently in complex emergencies. ${ }^{13,14}$ Few published studies have evaluated preventative or treatment measures for reducing child morbidity and mortality due to diarrhoeal diseases in complex emergencies, although the importance of clean water, appropriate sanitation, and rehydration is established. After a programme to distribute soap in a Malawi refugee camp for Mozambican refugees, households with soap reported $27 \%$ fewer episodes of diarrhoea than those without. ${ }^{15}$ In the same camps, prevention of household contamination of water with a covered container and spout reduced diarrhoeal disease in children younger than 5 years by $31 \% .^{16}$

\section{Measles}

Measles has been a major cause of child deaths in refugee camps and internally displaced populations, and also exacerbates malnutrition and vitamin $\mathrm{A}$ deficiency., ${ }^{4}, 17$ Many deaths attributed to diarrhoea and pneumonia may be associated with measles. Measles case-fatality ratios in children in complex emergencies have been as high as 20-30\%. ${ }^{18,19}$ During a famine in Ethiopia, measles alone or in combination with wasting accounted for $22 \%$ of 159 deaths of children under 5 years, and $17 \%$ of 72 deaths of children aged 5-14 years. ${ }^{20}$ Progress in global control has reduced the likelihood of measles outbreaks in some regions, although outbreaks can occur in refugee and internally displaced populations with low levels of immunity or vaccination coverage.

\section{Malaria}

The epidemiology and control of malaria in refugee camps and complex emergencies have been reviewed recently. ${ }^{21,22}$ As in stable situations, prevention of infection with insecticide-treated bednets, along with case-diagnosis and treatment, are important interventions to reduce morbidity and mortality. Indoor residual 
spraying with malathion in refugee camps in eastern Sudan in 1997 was associated with reduced mortality from, but not incidence of, clinical malaria. ${ }^{23}$ In Afghanistan, permethrin-treated Islamic cloth wraps (chaddars) used to sleep in and top-sheets reduced the odds of an episode of malaria by $64 \%$ in children younger than 10 years, at a cost of US\$ 0.17 per person protected. ${ }^{24}$ Deltamethrin-treated plastic tarpaulins in Afghan refugee camps effectively killed mosquitoes for prolonged periods. ${ }^{25}$

\section{Other communicable diseases}

Other infectious diseases can contribute substantially to child morbidity and mortality in complex emergencies. Recent examples include outbreaks of poliomyelitis in Angola, ${ }^{26}$ cutaneous leishmaniasis in Afghanistan, ${ }^{27}$ meningococcal meningitis in Sudanese refugee camps ${ }^{28}$ and typhoid fever in Bosnia and Herzegovina, ${ }^{29}$ Complex emergencies can disrupt tuberculosis control programmes and facilitate the transmission of Mycobacterium tuberculosis by exacerbating crowded living conditions and poor nutritional status, ${ }^{30}$ contributing to the transmission of multidrug-resistant strains. ${ }^{31}$ According to a report on the impact of war on children, HIV/AIDS (human immunodeficiency virus/acquired immunodeficiency syndrome) has changed the landscape of conflict for children more than any other factor. ${ }^{32}$ Conflict may increase vulnerability to HIV infection by worsening poverty, enhancing the transmission of sexually transmitted diseases to and from military personnel through rape and commercial sex, and through the recruitment of orphaned children into the sex industry. Whether a conflict results in enhanced HIV transmission depends on a complex interplay of individual and societal factors. ${ }^{33}$ However, little has been published on the epidemiology, prevention, diagnosis, and management of tuberculosis or HIV infection among children in complex emergencies, in particular in view of the obstacles to providing longterm care.

\section{Malnutrition and micronutrient deficiencies}

Malnutrition and micronutrient deficiencies contribute substantially to child morbidity and mortality in complex emergencies. ${ }^{3,4,34}$ Between 1988 and 1995, the median prevalence from 11 surveys of acute malnutrition among children under 5 years in internally displaced and conflict-affected populations was $31 \%$, and was as high as $80 \%$ in the Sudan in $1993 .{ }^{4}$ More recent surveys have found similar high prevalence rates of acute malnutrition in children in complex emergencies. ${ }^{20}$ Although much of the literature focuses on severe malnutrition, mild-to-moderate malnutrition is likely to be a significant underlying cause of death in children in complex emergencies, as it is in non-emergency situations.

Micronutrient deficiencies are common in refugee and displaced populations. ${ }^{35}$ Deficiencies found in children in non-refugee settings, e.g. iron and vita$\min \mathrm{A}$, are more common and severe in refugee or displaced children. In addition, uncommon micronutrient deficiencies, such as scurvy (vitamin C deficiency), pellagra (niacin and/or tryptophan), and beriberi (thiamine), may affect large populations in complex emergencies. ${ }^{35}$

Several studies demonstrated the effectiveness of supplementary and therapeutic feeding programmes in complex emergencies. Outpatient care for severely malnourished Ethiopian children showed acceptable recovery, default, and mortality rates, although rates of weight gain and time to discharge were slow. ${ }^{36}$

\section{Neonatal health}

Neonatal health has received scant attention in complex emergencies. A survey of pregnancy outcomes among Burundian refugees in the United Republic of Tanzania in 1998 found that neonatal and maternal deaths accounted for $16 \%$ of all deaths during the study period. ${ }^{37}$ The neonatal mortality rate was 29.3 per 1000 live births, and $22 \%$ of all live births were low birth weight. In a study of Afghan refugees in Pakistan, neonatal mortality accounted for $19 \%$ of all deaths and was the single largest "cause" of death. ${ }^{38}$

\section{Trauma}

Paediatric trauma is common during and after armed conflicts and natural disasters. The best-documented paediatric injuries associated with conflicts are those due to landmines. ${ }^{32,} 39$ In Afghanistan in the early 1990s, 25\% of injuries due to antipersonnel mines were in children younger than 16 years. ${ }^{40}$ In addition, the humanitarian response itself can cause injury: after the crisis in Rwanda, an influx of humanitarian relief vehicles and the practice of passing out biscuits and sweets to children from these vehicles, led to a reported increase in road-traffic accidents involving child pedestrians. ${ }^{39}$

\section{Mental health}

The mental health of children in complex emergencies, in particular after armed conflicts, has been studied. ${ }^{41,42}$ Many recent studies have been conducted in European cities and countries such as Bosnia and Herzegovina, ${ }^{43}$ Sarajevo, ${ }^{44}$ and Croatia, ${ }^{45}$ or have assessed the mental health of refugee children seeking asylum in developed countries. ${ }^{46,47}$ Most concluded that children exposed to armed conflict or the harsh living conditions of refugee camps have high rates of serious psychiatric problems. Although most studies report high rates of post-traumatic stress disorder (PTSD), depression and anxiety may affect larger numbers of children and contribute more to the long-term psychological burden. Few studies have assessed the mental health of refugee or internally displaced children who are not exiled to regions outside Europe or the United States. In a Sudanese refugee camp in northern Uganda, $20 \%$ of 56 children had chronic PTSD. ${ }^{48}$ By contrast, 58 Guatemalan Mayan Indian children living in refugee camps in Mexico showed little evidence of psychological trauma. ${ }^{49}$ The psychological consequences of war on children might not be permanent and irreparable, and might be mitigated by family and community support. ${ }^{50}$

\section{Unaccompanied children}

Some complex emergencies are associated with large numbers of unaccompanied children with special health-care needs. ${ }^{51,52}$ Although unaccompanied minors are often older children, in the Korean and Nigerian civil (Biafran) wars many were abandoned infants. ${ }^{53}$ Extremely high mortality rates were documented among unaccompanied Rwandan refugee children after arrival in Goma, Democratic Republic of the Congo. ${ }^{54}$ Most deaths (85\%) occurred more than 2 days after arrival at relief centres, suggesting that early and appropriate care could have significantly reduced mortality.

\section{Guidelines for the care of children in complex emergencies} The international relief organizations that we surveyed are listed in Box 1 . 
Although a few organizations have developed their own guidelines for the care of children in complex emergencies (e.g. Médecins sans Frontières, World Vision), most use WHO, United Nations Children's Fund (UNICEF), and ministry of health $(\mathrm{MOH})$ guidelines, some of which were developed for stable situations. Relief organizations use formal guidelines from these sources for the diagnosis and management of cholera, shigellosis, and meningococcal meningitis; management of severe dehydration, severe malnutrition, and micronutrient deficiencies; counselling on infant feeding; and measles case-management and immunization. In addition, organizations rely on WHO, UNICEF, and $\mathrm{MOH}$ guidelines for preventive care, including prevention of neonatal tetanus and malaria; routine childhood vaccination; promotion of breastfeeding; and routine vitamin A supplementation. Some organizations attempt to integrate nutritional management with routine child-health activities; for example, promotion of early and exclusive breastfeeding and encouragement of appropriate weaning foods.

Organizations were least likely to have formal guidelines on the management of asphyxia, prematurity, and infection in neonates; diagnosis and management of children with HIV infection; active case-finding and treatment of tuberculosis in children; paediatric trauma (e.g. burns, sexual abuse); emergency resuscitation; and the diagnosis and management of mental-health problems in children.

Guidelines often target health-care workers with more extensive medical training than those who usually provide care to children in complex emergencies. Some humanitarian organizations employ physicians, but nurses and clinical officers provide much of the care to children. In addition, most organizations recognize the importance of training community health workers and volunteers to provide care and disease surveillance. Hence, existing guidelines have limited applicability to the broad range of health-care workers employed in complex emergencies.

WHO generic guidelines on the Integrated Management of Childhood Illness (IMCI) could be clinically useful in complex emergencies because they address the major causes of morbidity and mortality and link therapeutic and preventative care. ${ }^{55}$ However, they have rarely been used in the acute phase. In transitional situations, some organizations reported working with ministries of health to implement IMCI in refugee camps as part of a national effort. IMCI guidelines were originally designed for use in established health centres; thus they need to be adapted to the conditions of complex emergencies. For example, village volunteers and community health workers have used a simplified version of IMCI where trained health-care workers were lacking. ${ }^{56}$ In many complex emergencies the infrastructure necessary to implement IMCI fully is not in place. For example, in emergency situations it is seldom possible to refer cases of serious illness to hospitals. IMCI guidelines can be enhanced when used in combination with emergency triage assessment and treatment (ETAT) guidelines. ETAT is designed to train health-care workers to assess rapidly severe disease and initiate resuscitation efforts. In complex emergencies many children present with severe disease, and rapid triage and treatment is critical to their successful management.

\section{Recommendations to improve child health in complex emergencies}

On the basis of our literature review and survey of international relief organizations, we recommend that to ensure appropriate, effective, and uniform care, evidence-based, locally adapted guidelines for the care of children in complex emergencies be adopted by ministries of health, supported by WHO and UNICEF, and disseminated to international relief organizations. This recommendation is based on three findings:

- most organizations caring for children in complex emergencies use clinical guidelines

- health care in complex emergencies is delivered by a wide range of different levels of health-care workers from numerous organizations

- guidelines for the prevention and management of child-health problems in complex emergencies exist but need to be brought together into an accessible, comprehensive package.

The clinical component should be adapted from existing clinical guidelines for the care of children in complex

Child health in complex emergencies

Box 1. International organizations surveyed

Action contre la Faim

Aga Khan Foundation

Africare

American Red Cross

American Refugee Committee

CARE International

Catholic Relief Services

Christian Children's Fund

Concern Worldwide

ECHO Health Services

ICDDR-B (Centre for Health and

Population Research?)

International Committee of the Red Cross

International Federation of the Red Cross/

Red Crescent

International Medical Corps

International Rescue Committee

Médecins du Monde

Médecins sans Frontières - Belgium

Médecins sans Frontières - USA

Mercy Corps

MERLIN

Samaritan's Purse

Save the Children-United Kingdom

UNICEF

World Bank

World Relief

World Vision

emergencies and stable situations (e.g. IMCI), but should focus on rapidly reducing mortality due to measles, malaria, diarrhoea (including cholera and shigellosis), acute respiratory tract infection, and acute malnutrition. The guidelines should address management of serious infections in the absence of referral facilities. They should address the health needs of special populations, including unaccompanied children and the mental health needs of traumatized children. Identification of research needs will arise from the process of developing comprehensive guidelines (Box 2).

International relief organizations should be a partner in developing and pre-testing guidelines to ensure they are appropriate to the level of health-care worker expected to provide the bulk of care to children in a complex emergency. The role of community health workers and volunteers should be recognized and defined, even when trained healthcare workers are present. In extreme situations, if health-care workers with advanced training are unavailable, simplified IMCI guidelines and training 


\section{Box 2. Research needed to improve child health in complex emergencies}

Develop and evaluate interventions to reduce neonatal mortality in complex emergencies

Develop and evaluate better tools to assess mental-health problems in children that can be applied across cultures

Develop and field-test rapid-diagnostic and antibiotic-susceptibility tests for Vibrio cholerae and Shigella dysenteriae

Evaluate the cost-effectiveness of short-course therapy for use in situations where compliance and follow-up are poor. Examples include:

- short-course therapy with ciprofloxacin for $S$. dysenteriae

- short-course therapy with macrolides for $V$. cholerae

- short-course therapy for pneumonia

- single-dose therapy for malaria

Evaluate intermittent presumptive treatment of malaria for children in complex emergencies

materials should be made available by WHO to allow community health workers and trained village volunteers to provide minimal basic care.

Guidelines developed by ministries of health, and adapted from those used in normal situations, should facilitate transition to a functional health-care system. Use of standardized and locally adapted guidelines by international relief organizations would strengthen national capacity to deal with prioritized health problems and link relief efforts with development.

Despite the complexities of addressing the health needs of children in emer- gencies, much of the burden of disease is caused by malnutrition and several infectious diseases that are common to children in many non-emergency settings and for which there exist evidencebased guidelines for prevention and treatment. This body of information and clinical experience is the foundation for addressing the health needs of children in complex emergencies. By describing areas where further work and research are needed, we hope that coordinated and concerted efforts can be made to improve child health and clinical outcomes in even the most acute emergencies.

\section{Acknowledgements}

We thank the participants of the WHOUNICEF Workshop on Child Health in Complex Emergencies, the organizations that responded to our surveys, and the anonymous reviewers.

Funding: This work was supported by a grant from the Department of Child and Adolescent Health, WHO to the Center for International Emergency, Disaster and Refugee Studies (CIEDRS) at the Johns Hopkins Bloomberg School of Public Health.

Competing interests: none declared.

\section{Résumé}

\section{La santé de l'enfant dans les situations d'urgence complexes}

Des interventions coordonnées et efficaces sont essentielles si I'on veut que les opérations de secours répondent aux besoins sanitaires des enfants dans les situations de conflit armé, de déplacement de populations et/ou d'insécurité alimentaire. II a été procédé à une revue de la littérature publiée et à une enquête auprès des organisations internationales de secours engagées dans des interventions en faveur de la santé infantile en situation d'urgence complexe. Le but était de définir les besoins en matière de recherche et d'améliorer les recommandations relatives aux soins apportés aux enfants. Une grande partie de la littérature porte sur la charge de morbidité et les causes de morbidité et de mortalité ; peu d'études internationales ont été publiées. Les enquêtes auprès des organisations internationales de secours ont révélé que la plupart d'entre elles appliquent des recommandations de I'Organisation mondiale de la Santé (OMS), du Fonds des Nations Unies pour l'Enfance (UNICEF) et du ministère de la santé conçues pour des situations stables. Les organisations disposaient plus rarement de directives officielles concernant la prise en charge de l'asphyxie, de la prématurité et des infections chez le nouveauné ; le diagnostic et la prise en charge des enfants contaminés par le virus de l'immunodéficience humaine $(\mathrm{VIH})$; le dépistage actif des cas et le traitement de la tuberculose ; les traumatismes pédiatriques et le diagnostic et le traitement des problèmes de santé mentale chez l'enfant. Souvent, les lignes directrices ne sont pas adaptées aux différents types d'agents de santé qui dispensent les soins dans les situations d'urgence complexes. Les ministères de la santé, avec l'appui de I'OMS et de I'UNICEF, devraient adopter des recommandations fondées sur des données factuelles et adaptées à la situation locale pour les soins dispensés aux enfants dans les situations d'urgence complexes et les diffuser auprès des organisations internationales de secours, afin de garantir l'adéquation, l'efficacité et la cohérence des soins.

\section{Resumen}

\section{La salud infantil en las emergencias complejas}

La buena coordinación y la eficacia de las intervenciones son requisitos fundamentales para atender con éxito las necesidades sanitarias de los niños en las situaciones de conflicto armado, desplazamiento de poblaciones y/o inseguridad alimentaria. Revisamos aquí la bibliografía al respecto y examinamos la labor de las organizaciones de socorro internacionales implicadas en las actividades de salud infantil en esas emergencias. Nuestro objetivo fue determinar las necesidades de investigación y mejorar las directrices de atención a los niños. Gran parte de la bibliografía describe la carga de morbilidad y las causas de la morbilidad y la mortalidad, pero los estudios de intervención publicados son escasos. Las encuestas realizadas entre las organizaciones de 
socorro internacionales mostraron que la mayor parte recurren a las directrices que la Organización Mundial de la Salud (OMS), el Fondo de las Naciones Unidas para la Infancia (UNICEF) y los ministerios de salud han concebido para situaciones estables. Las organizaciones carecían a menudo de directrices formales para el tratamiento de la asfixia, la prematuridad y las infecciones en los recién nacidos; el diagnóstico y tratamiento de los niños infectados por el virus de la inmunodeficiencia humana (VIH); la búsqueda activa de casos y el tratamiento de la tuberculosis; los traumatismos pediátricos; y el diagnóstico y tratamiento de los problemas de salud mental en los niños. Las directrices no suelen estar adaptadas a los diferentes tipos de agentes de atención sanitaria que intervienen en las emergencias complejas. Se necesitan directrices basadas en la evidencia y adaptadas a las condiciones locales para la atención de los niños en esas emergencias y dichas directrices deberían ser adoptadas por los ministerios de salud, respaldadas por la OMS y el UNICEF, y difundidas entre las organizaciones de socorro internacionales a fin de garantizar una atención apropiada, eficaz y uniforme.
دلائل إرشادية رسمية حول تدبير الاختناق والحنداج (الولادة قبل تمام الحمل)

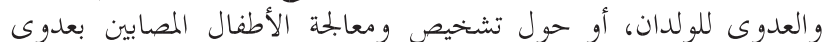

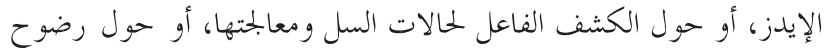

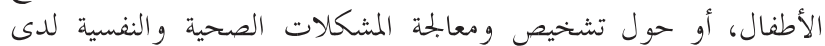

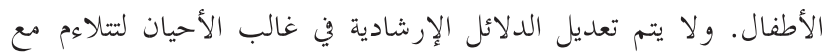

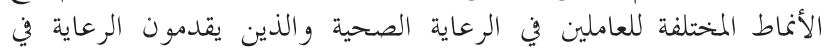

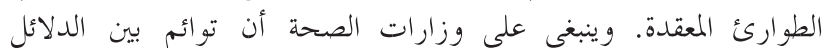

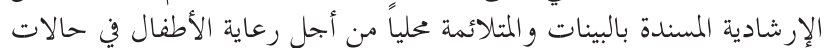

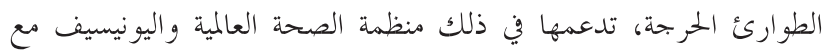

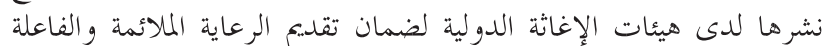

$$
\text { والمتجانسة. }
$$

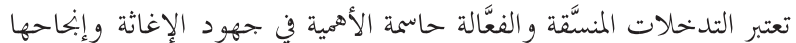

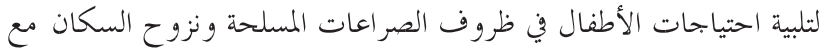

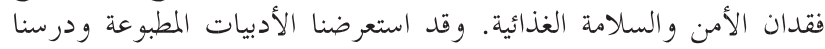

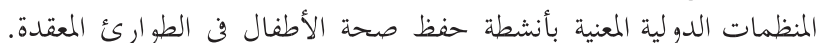

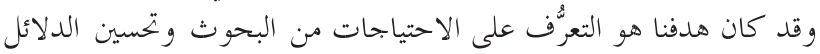

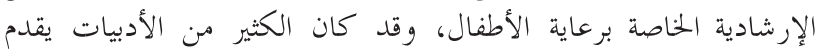

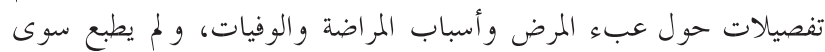

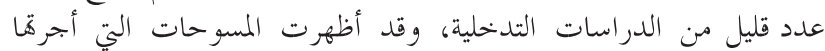

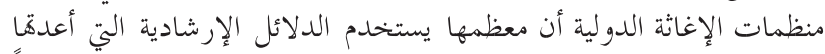

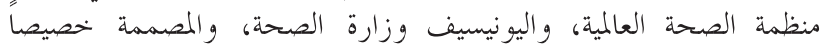

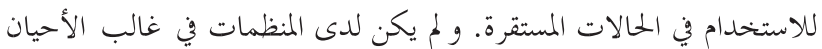

\section{References}

1. Salama P, Spiegel P, Talley L, Waldman R. Lessons learned from complex emergencies over past decade. Lancet 2004;364:1801-13.

2. Connolly MA, Gayer M, Ryan MJ, Salama P, Spiegel P, Heymann DL. Communicable diseases in complex emergencies: impact and challenges. Lancet 2004:364:1974-83.

3. Centers for Disease Control. Famine-affected, refugee, and displaced populations: recommendations for public health issues. MMWR Recomm Rep 1992;41:1-76.

4. Toole MJ, Waldman RJ. The public health aspects of complex emergencies and refugee situations. Annu Rev Public Health 1997;18:283-312.

5. Guha-Sapir D, Panhuis WG. Conflict-related mortality: an analysis of 37 datasets. Disasters 2004;28:418-28.

6. Toole MJ, Waldman RJ. Prevention of excess mortality in refugee and displaced populations in developing countries. JAMA 1990;263:3296-302.

7. Moore PS, Marfin AA, Quenemoen LE, Gessner BD, Ayub YS, Miller DS, et al. Mortality rates in displaced and resident populations of central Somalia during 1992 famine. Lancet 1993;341:935-8.

8. Nabeth P, Vasset B, Guerin P, Doppler B, Tectonidis M. Health situation of refugees in eastern Zaire. Lancet 1997;349:1031-2.

9. Paquet $C$, van Soest M. Mortality and malnutrition among Rwandan refugees in Zaire. Lancet 1994:344:823-4.

10. Spiegel PB, Salama P. War and mortality in Kosovo, 1998-99: an epidemiological testimony. Lancet 2000;355:2204-9.

11. Black RE, Morris SS, Bryce J. Where and why are 10 million children dying every year? Lancet 2003;361:2226-34.

12. Talley L, Spiegel PB, Girgis M. An investigation of increasing mortality among Congolese refugees in Lugufu Camp, Tanzania, May-June 1999. J Refug Stud 2001;14:412-27.

13. Siddique AK, Salam A, Islam MS, Akram K, Majumdar RN, Zaman K, et al. Why treatment centres failed to prevent cholera deaths among Rwandan refugees in Goma, Zaire. Lancet 1995;345:359-61.

14. Swerdlow DL, Malenga G, Begkoyian G, Nyangulu D, Toole M, Waldman RJ, et al. Epidemic cholera among refugees in Malawi, Africa: treatment and transmission. Epidemiol Infect 1997;118:207-14.
15. Peterson EA, Roberts L, Toole MJ, Peterson DE. The effect of soap distribution on diarrhoea: Nyamithuthu Refugee Camp. Int J Epidemiol 1998;27:520-4.

16. Roberts L, Chartier Y, Chartier O, Malenga G, Toole M, Rodka H. Keeping clean water clean in a Malawi refugee camp: a randomized intervention trial. Bull World Health Organ 2001;79:280-7.

17. Toole MJ, Steketee RW, Waldman RJ, Nieburg P. Measles prevention and control in emergency settings. Bull World Health Organ 1989;67:381-8.

18. Shears $P$, Berry AM, Murphy R, Nabil MA. Epidemiological assessment of the health and nutrition of Ethiopian refugees in emergency camps in Sudan, 1985. BMJ (Clin Res Ed) 1987;295:314-8.

19. Porter JD, Gastellu-Etchegorry M, Navarre I, Lungu G, Moren A. Measles outbreaks in the Mozambican refugee camps in Malawi: the continued need for an effective vaccine. Int J Epidemiol 1990;19:1072-7.

20. Salama P, Assefa F, Talley L, Spiegel P, van Der V, Gotway CA. Malnutrition, measles, mortality, and the humanitarian response during a famine in Ethiopia. JAMA 2001;286:563-71.

21. Rowland M, Nosten F. Malaria epidemiology and control in refugee camps and complex emergencies. Ann Trop Med Parasitol 2001;95:741-54.

22. Bloland $\mathrm{PB}$, Williams HA. Malaria control during mass population movements and natural disasters. Washington (DC): The National Academies Press; 2003.

23. Charlwood JD, Qassim M, Elnsur El, Donnelly M, Petrarca V, Billingsley PF, et al. The impact of indoor residual spraying with malathion on malaria in refugee camps in eastern Sudan. Acta Tropica 2001;80:1-8.

24. Rowland M, Durrani N, Hewitt S, Mohammed N, Bouma M, Carneiro I, et al. Permethrin-treated chaddars and top-sheets: appropriate technology for protection against malaria in Afghanistan and other complex emergencies. Trans R Soc Trop Med Hyg 1999;93:465-72.

25. Graham K, Mohammad N, Rehman H, Nazari A, Ahmad M, Kamal M, et al. Insecticide-treated plastic tarpaulins for control of malaria vectors in refugee camps. Med Vet Entomol 2002;16:404-8.

26. Valente F, Otten M, Balbina F, Van de WR, Chezzi C, Eriki P, et al. Massive outbreak of poliomyelitis caused by type-3 wild poliovirus in Angola in 1999. Bull World Health Organ 2000;78:339-46. 
27. Rowland M, Munir A, Durrani N, Noyes H, Reyburn H. An outbreak of cutaneous leishmaniasis in an Afghan refugee settlement in north-west Pakistan. Trans R Soc Trop Med Hyg 1999;93:133-6.

28. Santaniello-Newton A, Hunter PR. Management of an outbreak of meningococcal meningitis in a Sudanese refugee camp in Northern Uganda. Epidemiol Infect 2000;124:75-81.

29. Bradaric N, Punda-Polic V, Milas I, Ivic I, Grgic D, Radosevic N, et al. Two outbreaks of typhoid fever related to the war in Bosnia and Herzegovina. Eur J Epidemiol 1996:12:409-12.

30. Barr RG, Menzies R. The effect of war on tuberculosis. Results of a tuberculin survey among displaced persons in El Salvador and a review of the literature. Tuber Lung Dis 1994;75:251-9.

31. Githui WA, Hawken MP, Juma ES, Godfrey-Faussett P, Swai OB, Kubuga DK, et al. Surveillance of drug-resistant tuberculosis and molecular evaluation of transmission of resistant strains in refugee and non-refugee populations in North-Eastern Kenya. Int J Tuberc Lung Dis 2000;4:947-55.

32. Machel G. The impact of war on children. London: Hurst and Company; 2001

33. Spiegel PB. HIVIAIDS among conflict-affected and displaced populations: dispelling myths and taking action. Disasters 2004;28:322-39.

34. Toole MJ, Waldman RJ. Refugees and displaced persons. War, hunger and public health. JAMA 1993;270:600-5.

35. Weise $P Z$, de Benoist $B$. Meeting the challenges of micronutrient deficiencies in emergency-affected populations. Proc Nutr Soc 2002;61:251-7.

36. Collins $S$, Sadler K. Outpatient care for severely malnourished children in emergency relief programmes: a retrospective cohort study. Lancet 2002; 360:1824-30

37. Jamieson DJ, Meikle SF, Hillis SD, Mtsuko D, Mawji S, Duerr A. An evaluation of poor pregnancy outcomes among Burundian refugees in Tanzania. JAMA 2000;283:397-402.

38. Bartlett LA, Jamieson DJ, Kahn T, Sultana M, Wilson HG, Duerr A. Maternal mortality among Afghan refugees in Pakistan, 1999-2000. Lancet 2002; 359:643-9.

39. Pearn J. War zone paediatrics in Rwanda. J Paediatr Child Health 1996; 32:290-5.

40. Jeffrey SJ. Antipersonnel mines: who are the victims? J Accid Emerg Med 1996:13:343-6.

41. McCloskey LA, Southwick K. Psychosocial problems in refugee children exposed to war. Pediatrics 1996;97:394-7.

42. Plunkett MC, Southall DP. War and children. Arch Dis Child 1998;78:72-7.
43. Smith P, Perrin S, Yule W, Hacam B, Struvland R. War exposure among children from Bosnia-Hercegovina: psychological adjustment in a community sample. J Trauma Stress 2002;15:147-56.

44. Allwood MA, Bell-Dolan D, Husain SA. Children's trauma and adjustment reactions to violent and nonviolent war experiences. J Am Acad Child Adolesc Psychiatry 2002;41:450-7.

45. Kuterovac G, Dyregrov A, Stuvland R. Children in war: a silent majority under stress. Br J Med Psychol 1994;67:363-75.

46. Fazel $M$, Stein $A$. The mental health of refugee children. Arch Dis Child 2002;87:366-70

47. Rothe EM, Lewis J, Castillo-Matos H, Martinez R, Martinez I. Posttraumatic stress disorder among Cuban children and adolescents after release from a refugee camp. Psychiatr Serv 2002;53:970-6.

48. Peltzer K. Trauma and mental health problems of Sudanese refugees in Uganda. Cent Afr J Med 1999:45:110-4.

49. Miller KE. The effects of state terrorism and exile on indigenous Guatemalan refugee children: a mental health assessment and an analysis of children's narratives. Child Dev 1996;67:89-106

50. Summerfield D. Children affected by war must not be stigmatized as permanently damaged [letter]. BMJ 1998:317:1249.

51. Ressler EM, Boothby N, Steinbock DJ. Unaccompanied children: care and protection in wars, natural disasters, and refugee movements. New York: Oxford University Press; 1988

52. United Nations Children's Fund/United Nations High Commissioner for Refugees Joint Task Force. Standards for Protection and Care of Unaccompanied Refugee Children; Rwanda Refugee Operation, Goma (Zaire). New York: United Nations Children's Fund; 1994.

53. Sapir DG. Natural and man-made disasters: the vulnerability of womenheaded households and children without families. World Health Stat Q 1993; 46:227-33.

54. Dowell SF, Toko A, Sita C, Piarroux R, Duerr A, Woodruff BA. Health and nutrition in centers for unaccompanied refugee children. Experience from the 1994 Rwandan refugee crisis. JAMA 1995;273:1802-6.

55. World Health Organization, United Nations Children's Fund. Integrated Management of Childhood IIIness. WHO/FCH/CAH/01.01. Geneva: World Health Organization; 2001

56. Beltramello C, Zagaria N, Masiello L, Robinson D. Where there is no health worker - saving children's lives in southern Sudan. Health Exchange 2002 April:19-22. 